\title{
KAJIAN EMPIRIS ENTREPRENEURIAL INTENTION MAHASISWA STIE AMA SALATIGA
}

\author{
Oleh : \\ Yanuar Surya Putra \\ Dosen Tetap STIE AMA Salatiga
}

\begin{abstract}
Abstrak
Theory of Planned Behavior menyatakan bahwa niat seseorang untuk melakukan suatu perilaku, niat merupakan variabel antara yang menyebabkan terjadinya perilaku dari suatu sikap maupun variabel lainnya (Ajzen, 1991). Niat merupakan mediator pengaruh berbagai faktor-faktor motivasional yang berdampak pada suatu perilaku.. Penggunaan teori perilaku tidak dapat dipisahkan dari aspek motivasi berwirausaha atau entrepreneurial intention, artinya kewirausahaan dapat dipelajari dan dikuasai, dan kewirausahaan dapat menjadi pilihan kerja dan pilihan karir bagi lulusan perguruan tinggi, apabila memang dalam diri mahasiswa ada niat dan motivasi untuk menjadi seorang entrepreneur. Adapun tujuan penelitian untuk menguji pengaruh kebutuhan berprestasi (neef for achievement), normal subyektif (subjective norm), efikasi diri (self-efficacy) dan terhadap niat berwirausaha (entrepreneurial intention) mahasiswa, selain itu juga untuk menganalisis perbedaan gender, dan latar belakang keluarga terhadap level entrepreneurial intention mahasiswa STIE AMA Salatiga.

Populasi pada penelitian ini adalah mahasiswa STIE AMA Salatiga yang berjumlah 921 orang. Teknik sampling yang digunakan adalah teknik purposive sampling, yaitu pengambilan sampel dengan kriteria atau syarat tertentu (Sugiyono, 2008).Penentuan jumlah responden yang akan dibagikan adalah 30 orang didasarkan pada mahasiswa yang pada semester gasal 2016/2017 sudah atau sedang mengambil mata kuliah kewirausahaan. Penelitian ini menggunakan teknik analisis data yaitu regresi berganda dengan uji nilai selisih mutlak. Dari hasil uji selisih nilai mutlak dapat disimpulkan bahwa variabel demografi hanya menjadi moderator bagi variabel need of achievement saja, sedangkan bagi variabel subjective norms dan self efficacy faktor demografi bukan sebagai variabel moderasi. Kesimpulan akhir penelitian ini dapat dikatakan bahwa faktor demografi adalah variabel quasi moderator bukan variabel moderator murni karena faktor demografi hanya berhubungan dengan satu predictor saja yaitu need of achievement. Minat berwirausaha dari mahasiswa STIE AMA Salatiga dipengaruhi oleh tiga variabel yaitu need of achievement, subjective norms dan self efficacy, sedangkan faktor demografi bukan sebagai variabel moderasi yang memperkuat atau memperlemah minat berwirausaha.
\end{abstract}

Kata Kunci: Theory of Planned Behaviour, Entrepreneurial Intention

Kajian Empiris Entrepreneurial Intention Mahasiswa STIE AMA Salatiga (Yanuar Surya Putra) 


\section{PENDAHULUAN}

Pengembangan kewirausahaan beberapa tahun terakhir memang telah menjadi isu lembaga-lembaga ekonomi mulai dari tingkat daerah, nasional bahkan internasional. Kecenderungan ini karena keyakinan bahwa kewirausahaan adalah kunci untuk sejumlah hasil-hasil sosial yang diinginkan, termasuk pertumbuhan ekonomi, pengangguran yang lebih rendah, dan modernisasi teknologi (Baumol, et al. 2007). Pertanyaan yang sering dikemukakan oleh para ahli adalah "Apa yang membuat beberapa orang lebih berjiwa kewirausahaan dari yang lain? Dapatkah para pembuat kebijakan melakukan sesuatu untuk mengembangkan jiwa kewirausahaan?” (Licht, 2007).

Theory of Planned Behavior menyatakan bahwa niat seseorang untuk melakukan suatu perilaku, niat merupakan variabel antara yang menyebabkan terjadinya perilaku dari suatu sikap maupun variabel lainnya (Ajzen, 1991). Niat merupakan mediator pengaruh berbagai faktor-faktor motivasional yang berdampak pada suatu perilaku. Di samping itu, niat juga menunjukkan seberapa keras seseorang berani mencoba, niat menunjukkan seberapa besar upaya yang direncanakan seseorang untuk dilakukannya dan niat adalah paling dekat berhubungan dengan perilaku selanjutnya (Wijaya, 2008). Penggunaan teori perilaku tidak dapat dipisahkan dari aspek motivasi berwirausaha atau entrepreneurial intention, artinya kewirausahaan dapat dipelajari dan dikuasai, dan kewirausahaan dapat menjadi pilihan kerja dan pilihan karir bagi lulusan perguruan tinggi, apabila memang dalam diri mahasiswa ada niat dan motivasi untuk menjadi seorang entrepreneur. Seberapa besar entrepreneurial intention atau motivasi mahasiswa menjadi wirausaha tentunya akan dipengaruhi atau ditentukan oleh beberapa faktor. Oleh karena itu perlu diketahui faktor-faktor yang mempengaruhi motivasi mahasiswa untuk menjadi entrepreneur atau intensi menjadi entrepreneur.

Hasil-hasil penelitian tentang entrepreneurial intention dari beberapa peneliti ternyata masih memiliki perbedaan, misalnya Indarti dan Rosiani (2008) menyatakan bahwa efikasi diri terbukti mempengaruhi intensi mahasiswa, sedangkan Wijaya (2008); Segal (2005); menyatakan bahwa efikasi diri terbukti tidak mempengaruhi intensi berwirausaha. Demikian juga lingkungan tidak terbukti sebagai faktor penyebab keinginan berwirausaha (Ismail, 2009; Zain et al., 2010), sedangkan Alstete (2002) menyatakan dorongan 
berwirausaha karena lingkungan eksternal seperti pengangguran, frustasi dengan pekerjaan sebelumnya dan kebutuhan untuk mendapatkan hidup layak. Faktor pengalaman bekerja menurut Indarti dan Rosiani (2008) menjadi faktor penentu intensi kewirausahaan bagi mahasiswa, sedangkan menurut Ismail (2009) ternyata tidak ada perbedaan siswa yang memiliki pengalaman dan tidak memiliki pengalaman dalam kegiatan usaha dalam menimbulkan niat berwirausaha. Berdasarkan hasil-hasil penelitian terdahulu tersebut masih memunculkan pertanyaan sebenarnya faktor-faktor apa yang mempengaruhi niat berwirausaha (entrepreneurial intention) seseorang. Apakah kebutuhan berprestasi (need for achievement), norma subyektif (subjective norm), dan efikasi diri (self-efficacy) memiliki pengaruh terhadap niat berwirausaha (entrepreneurial intention) mahasiswa, serta apakah perbedaan gender, dan latar belakang keluarga membedakan level entrepreneurial intention mahasiswa.

Secara umum, faktor anteseden intensi dapat diungkapkan melalui Theory Planned of Behavior (TPB) yaitu keyakinan atau sikap berperilaku, norma subjektif dan kontrol perilaku. Terbentuknya intensi dapat diterangkan dengan teori perilaku terencana yang mengasumsikan manusia selalu mempunyai tujuan dalam berperilaku (Ajzen, 2001). Teori ini menyebutkan bahwa intensi adalah fungsi dari tiga determinan dasar, yaitu : (1) Sikap berperilaku (attitude), yang merupakan dasar bagi pembentukan intensi. Di dalam sikap terhadap perilaku terdapat dua aspek pokok, yaitu : keyakinan individu bahwa menampilkan atau tidak menampilkan perilaku tertentu akan menghasilkan akibat-akibat atau hasil-hasil tertentu, dan merupakan aspek pengetahuan individu tentang obyek sikap dapat pula berupa opini individu hal yang belum tentu sesuai dengan kenyataan. Semakin positif keyakinan individu akan akibat dari suatu obyek sikap, maka akan semakin positif pula sikap individu terhadap obyek sikap tersebut, demikian pula sebaliknya (Ajzen, 2001); (2) Norma subjektif (subjective norm), yaitu keyakinan individu akan norma, orang sekitarnya dan motivasi individu untuk mengikuti norma tersebut. Di dalam norma subjektif terdapat dua aspek pokok yaitu : keyakinan akan harapan, harapan norma referensi, merupakan pandangan pihak lain yang dianggap penting oleh individu yang menyarankan individu untuk menampilkan atau tidak menampilkan perilaku tertentu 
serta motivasi kesediaan individu untuk melaksanakan atau tidak melaksanakan pendapat atau pikiran pihak lain yang dianggap penting bahwa individu harus atau tidak harus berperilaku; (3) Kontrol perilaku (perceived feasiable), yang merupakan dasar bagi pembentukan kontrol perilaku yang dipersepsikan. Kontrol perilaku yang dipersepsi merupakan persepi terhadap kekuatan faktor-faktor yang mempermudah atau mempersulit suatu perilaku. Dalam beberapa penelitian kewirausahaan, kontrol perilaku dioperasionalkan dalam bentuk efikasi diri; (4) Niat untuk melakukan perilaku (intention) adalah kecenderungan seseorang untuk memilih melakukan atau tidak melakukan sesuatu pekerjaan. Niat ini ditentukan oleh sejauh mana individu memiliki sikap positif pada perilaku tertentu, dan sejauh mana kalau dia memilih untuk melakukan perilaku tertentu itu dia mendapat dukungan dari orang lain yang berpengaruh dalam kehidupannya.

Beberapa penelitian-penelitian terdahulu menunjukkan bahwa faktor-faktor demografis seperti gender, umur, pendidikan dan pengalaman bekerja seseorang berpengaruh terhadap keinginannya untuk menjadi seorang wirausaha (Mazzarol et al., 1999; Tkachev dan Kolvereid, 1999). Intensi memainkan peranan yang khas dalam mengarahkan tindakan, yakni menghubungkan antara pertimbangan yang mendalam yang diyakini dan diinginkan oleh seseorang dengan tindakan tertentu. Intensi adalah kesungguhan niat seseorang untuk melakukan perbuatan atau memunculkan suatu perilaku tertentu (Wijaya, 2007). Secara umum, faktor anteseden intensi dapat diungkapkan melalui Theory Planned of Behavior (TPB) yaitu keyakinan atau sikap berperilaku, norma subjektif dan kontrol perilaku. Terbentuknya intensi dapat diterangkan dengan teori perilaku terencana yang mengasumsikan manusia selalu mempunyai tujuan dalam berperilaku (Fisbein\& Ajzen, 1975). Indarti dan Rosiani (2008) menyatakan bahwa efikasi diri terbukti mempengaruhi intensi mahasiswa, sedangkan hasil penelitian Wijaya (2008); Segal (2005); menyatakan bahwa efikasi diri terbukti tidak mempengaruhi intensi berwirausaha. Demikian juga lingkungan tidak terbukti sebagai faktor penyebab keinginan berwirausaha (Ismail, 2009; Zain et al., 2010), sedangkan Alstete (2002) menyatakan dorongan berwirausaha karena lingkungan eksternal seperti pengangguran, frustasi dengan pekerjaan sebelumnya dan kebutuhan untuk mendapatkan hidup layak. Faktor pengalaman bekerja menurut Indarti dan Rosiani (2008) menjadi faktor penentu intensi kewirausahaan bagi mahasiswa, 
sedangkan menurut Ismail (2009) ternyata tidak ada perbedaan siswa yang memiliki pengalaman dan tidak memiliki pengalaman dalam kegiatan usaha dalam menimbulkan niat berwirausaha.

Berdasarkan beberapa hasil penelitian tentang faktor-faktor yang mempengaruhi intensi mahasiswa untuk berwirausaha dan masih adanya perbedaan hasil, maka dalam penelitian ini akan diadopsi Teori Planned Behavior untuk menguji kembali faktor yang mempengaruhi intensi mahasiswa untuk berwirausaha yaitu norma subyektif dan efikasi diri, serta faktor-faktor yang dirumuskan oleh Shane (2003) yaitu efikasi diri dan faktor demografis seperti umur, gender, latar belakang pendidikan, dan pengalaman. Terbentuknya intensi dapat diterangkan dengan teori perilaku terencana yang mengasumsikan manusia selalu mempunyai tujuan dalam berperilaku (Ajzen, 2001). Teori Planned Behavior menyebutkan bahwa intensi adalah fungsi dari tiga determinan dasar yaitu keyakinan atau sikap berperilaku (attitude), norma subjektif (subjective norm) dan efikasi diri. STIE AMA Salatiga adalah Perguruan Tinggi swasta yang memiliki visi untuk menghasilkan lulusan yang berkarakter entrepreneurship, sehingga penanaman jiwa kewirausahaan menjadi hal yang sangat mendasar. STIE AMA memiliki 4 program studi dengan student body yang berkisar 900an mahasiswa maka perlu dilakukan penelitian apakah yang mempengaruhi minat berwirausaha mahasiswa, sehingga visi STIE AMA dapat tercapai. Berdasarkan uraian tersebut maka masalah peneltian yang diangkat adalah Kajian Empiris Entrepreneurial Intention Mahasiswa STIE AMA Salatiga.

\section{Rumusan Masalah}

Maka berdasarkan pada uraian tersebut pertanyaan penelitian ini adalah:

1. Apakah terdapat pengaruh need for achievement terhadap minat berwirausaha pada mahasiswa STIE AMA Salatiga dengan faktor demografis sebagai variabel moderating?

2. Apakah terdapat pengaruh subjective norm terhadap minat berwirausaha pada mahasiswa STIE AMA Salatiga dengan faktor demografis sebagai variabel moderating? 
3. Apakah terdapat pengaruh self efficacy terhadap minat berwirausaha pada mahasiswa STIE AMA Salatiga dengan faktor demografis sebagai variabel moderating?

\section{Tujuan Penelitian}

Tujuan dalam suatu penelitian adalah menjawab persoalan penelitian yang diangkat, dalam penelitian ini tujuannya adalah sebagai berikut :

1. Untuk mengetahui pengaruh need for achievement terhadap minat berwirausaha pada mahasiswa STIE AMA Salatiga dengan faktor demografis sebagai variabel moderating.

2. Untuk mengetahui pengaruh subjective norm terhadap minat berwirausaha pada mahasiswa STIE AMA Salatiga dengan faktor demografis sebagai variabel moderating.

3. Untuk mengetahui pengaruh self efficacy terhadap minat berwirausaha pada mahasiswa STIE AMA Salatiga dengan faktor demografis sebagai variabel moderating.

\section{LANDASAN TEORI}

\section{Theory of Planned Behavior}

Theory Reasoned Action (TRA) pertama kali dicetuskan oleh Ajzen pada tahun 1980 (Jogiyanto, 2007). Teori ini disusun menggunakan asumsi dasar bahwa manusia berperilaku dengan cara yang sadar dan mempertimbangkan segala informasi yang tersedia. Dalam TRA ini, Ajzen (1980) yang menyatakan bahwa seseorang dapat melakukan atau tidak melakukan suatu perilaku tergantung dari niat yang dimiliki oleh orang tersebut. Lebih lanjut, Ajzen (1980) mengemukakan bahwa niat melakukan atau tidak melakukan perilaku tertentu dipengaruhi oleh dua penentu dasar, yang pertama berhubungan dengan sikap (attitude towards behavior) dan yang lain berhubungan dengan pengaruh sosial yaitu norma subjektif (subjective norms). Dalam upaya mengungkapkan pengaruh sikap dan norma subjektif terhadap niat untuk dilakukan atau tidak dilakukannya perilaku, Ajzen melengkapi TRA ini dengan keyakinan (beliefs). Dikemukakannya bahwa sikap berasal dari keyakinan terhadap perilaku (behavioral 
beliefs), sedangkan norma subjektif berasal dari keyakinan normatif (normative beliefs). Model teoritik dari Teori Planned Behavior (Perilaku yang direncanakan) mengandung berbagai variabel yaitu :

\section{Latar belakang (background factors)}

Seperti usia, jenis kelamin, suku, status sosial ekonomi, suasana hati, sifat kepribadian, dan pengetahuan) mempengaruhi sikap dan perilaku individu terhadap sesuatu hal. Faktor latar belakang pada dasarnya adalah sifat yang hadir di dalam diri seseorang, yang dalam model Kurt Lewin dikategorikan ke dalam aspek O (organism). Dalam kategori ini Ajzen (2005), memasukkan tiga faktor latar belakang, yakni personal, sosial, dan informasi. Faktor personal adalah sikap umum seseorang terhadap sesuatu, sifat kepribadian (personality traits), nilai hidup (values), emosi, dan kecerdasan yang dimilikinya. Faktor sosial antara lain adalah usia, jenis kelamin (gender), etnis, pendidikan, penghasilan, dan agama. Faktor informasi adalah pengalaman, pengetahuan, dan ekspose pada media.

\section{Keyakinan perilaku (behavioral belief)}

Hal-hal yang diyakini oleh individu mengenai sebuah perilaku dari segi positif dan negatif, sikap terhadap perilaku atau kecenderungan untuk bereaksi secara afektif terhadap suatu perilaku, dalam bentuk suka atau tidak suka pada perilaku tersebut.

2. Keyakinan normatif (normative beliefs)

Berkaitan langsung dengan pengaruh lingkungan yang secara tegas dikemukakan oleh Lewin dalam Field Theory. Pendapat Lewin ini digaris bawahi juga oleh Ajzen melalui perceived behavioral control. Menurut Ajzen (2005), faktor lingkungan sosial khususnya orang-orang yang berpengaruh bagi kehidupan individu (significant others) dapat mempengaruhi keputusan individu.

3. Norma subjektif (subjective norm) 
Sejauh mana seseorang memiliki motivasi untuk mengikuti pandangan orang terhadap perilaku yang akan dilakukannya (Normative Belief). Kalau individu merasa itu adalah hak pribadinya untuk menentukan apa yang akan dia lakukan, bukan ditentukan oleh orang lain disekitarnya, maka dia akan mengabaikan pandangan orang tentang perilaku yang akan dilakukannya. Fishbein dan Ajzen (1975), menggunakan istilah "motivation to comply" untuk menggambarkan fenomena ini, yaitu apakah individu mematuhi pandangan orang lain yang berpengaruh dalam hidupnya atau tidak.

5. Keyakinan dari dalam diri individu bahwa suatu perilaku yang dilaksanakan (control beliefs) dapat diperoleh dari berbagai hal, pertama adalah pengalaman melakukan perilaku yang sama sebelumnya atau pengalaman yang diperoleh karena melihat orang lain misalnya, teman, keluarga dekat dalam melaksanakan perilaku itu sehingga ia memiliki keyakinan bahwa ia pun akan dapat melaksanakannya. Selain pengetahuan, ketrampilan, dan pengalaman, keyakinan individu mengenai suatu perilaku akan dapat dilaksanakan ditentukan juga oleh ketersediaan waktu untuk melaksanakan perilaku tersebut, tersedianya fasilitas untuk melaksanakannya, dan memiliki kemampuan untuk mengatasi setiap kesulitan yang menghambat pelaksanaan perilaku.

6. Persepsi kemampuan mengontrol tingkah laku (perceived behavioral control) Keyakinan (beliefs) bahwa individu pernah melaksanakan atau tidak pernah melaksanakan perilaku tertentu, individu memiliki fasilitas dan waktu untuk melakukan perilaku itu, kemudian individu melakukan estimasi atas kemampuan dirinya apakah dia punya kemampuan atau tidak memiliki kemampuan untuk melaksanakan perilaku tersebut. Ajzen (2005) menamakan kondisi ini dengan "persepsi kemampuan mengontrol" (perceived behavioral control). Niat untuk melakukan perilaku (intention) adalah kecenderungan seseorang untuk memilih melakukan atau tidak melakukan sesuatu pekerjaan. Niat ini ditentukan oleh sejauh mana individu memiliki sikap positif pada perilaku tertentu, dan sejauh mana kalau dia memilih untuk melakukan 
perilaku tertentu itu dia mendapat dukungan dari orang-orang lain yang berpengaruh dalam kehidupannya.

Menurut Theory of Planned Behavior, seseorang dapat bertindak berdasarkan intensi atau niatnya hanya jika ia memiliki kontrol terhadap perilakunya (Ajzen, 2002). Teori ini tidak hanya menekankan pada rasionalitas dari tingkah laku manusia, tetapi juga pada keyakinan bahwa target tingkah laku berada di bawah kontrol kesadaran individu tersebut atau suatu tingkah laku tidak hanya bergantung pada intensi seseorang, melainkan juga pada faktor lain yang tidak ada dibawah kontrol dari individu, misalnya ketersediaan sumber dan kesempatan untuk menampilkan tingkah laku tersebut (Ajzen, 2005). Dari sini lah Ajzen memperluas teorinya dengan menekankan peranan dari kamuan yang kemudian disebut sebagai Perceived Behavioral Control (Vaughan \& Hogg, 2005).

Berdasarkan Theory of Planed Behavior, intensi merupakan fungsi dari tiga determinan, yang satu yang bersifat personal, kedua merefleksikan pengaruh sosial dan ketiga berhubungan dengan masalah kontrol (Ajzen, 2005). Berikut ini adalah penjabaran dari variabel utama dari Theory of Planned Behavior yang terdiri dari: intensi, attitude toward behavior, subjective norms, dan perceived behavioral control.

\section{Intensi}

Intensi menurut Fishbein dan Ajzen (1975), merupakan komponen dalam diri individu yang mengacu pada keinginan untuk melakukan tingkah laku tertentu. ntensi didefinisikan sebagai dimensi probabilitas subjektif individu dalam kaitan antara diri dan perilaku. Bandura (1986), menyatakan bahwa intensi merupakan suatu kebulatan tekad untuk melakukan aktivitas tertentu atau menghasilkan suatu keadaan tertentu di masa depan. Intensi menurutnya adalah bagian vital dari Self regulation individu yang dilatarbelakangi oleh motivasi seseorang untuk bertindak. Merangkum pendapat di atas, Santoso (1995) beranggapan bahwa intensi adalah hal-hal yang diasumsikan dapat menjelaskan faktor-faktor motivasi serta berdampak kuat pada tingkah laku. Hal ini 
mengindikasikan seberapa keras seseorang berusaha dan seberapa banyak usaha yang dilakukan agar perilaku yang diinginkan dapat dilakukan.

Menurut Theory of Planned Behavior, seseorang dapat bertindak berdasarkan intensi atau niatnya hanya jika ia memiliki kontrol terhadap perilakunya (Ajzen, 2002). Teori ini tidak hanya menekankan pada rasionalitas dari tingkah laku manusia, tetapi juga pada belief bahwa target tingkah laku berada di bawah kontrol kesadaran individu tersebut. Suatu tingkah laku tidak hanya bergantung pada intensi seseorang, melainkan juga pada faktor lain yang tidak ada dibawah kontrol dari individu, misalnya ketersediaan sumber dan kesempatan untuk menampilkan tingkah laku tersebut (Ajzen, 2005).

Intensi merupakan sebuah istilah yang terkait dengan tindakan dan merupakan unsur yang penting dalam sejumlah tindakan, yang menunjukan pada keadaan pikiran seseorang yang diarahkan untuk melakukan sesuatu tindakan, yang senyatanya dapat atau tidak dapat dilakukan dan diarahkan entah pada tindakan sekarang atau pada tindakan yang akan datang. Intensi memainkan peranan yang khas dalam mengarahkan tindakan, yakni menghubungkan antara pertimbangan yang mendalam yang diyakini dan diinginkan oleh seseorang dengan tindakan tertentu. Berdasarkan uraian di atas dapat disimpulkan bahwaintensi adalah kesungguhan niat seseorang untuk melakukan perbuatan atau memunculkan suatu perilaku tertentu. Berdasarkan Theory Of Planned Behavior, intensi terbentuk dari attitude toward behavior, subjective norms, dan perceived behavioral control yang dimiliki individu terhadap suatu perilaku.

\section{Entrepreneurial Intention}

Minat adalah suatu perangkat mental yang terdiri dari suatu campuran dari perasaan, harapan, pendirian, prasangka, rasa takut atau kecenderungan-kecenderungan lain yang mengarahkan individu kepada suatu pilihan tertentu. Sedangkan cita-cita merupakan perwujudan dari minat, dalam hubungan dengan prospek (jangkauan masa depgan_ dimana seseorang merencanakan dan menentukan pilihan terhadap pendidikan, jabatan serta teman hidup (Mappiare, 1982). Hurlock (1991) menyatakanbahwa minat adalah motif yang menunjukkan arah perhatian individu kepada obyek yang menarik serta menyenangkan, apabila individu berminat terhadap obyek atau aktivitas tertentu maka ia akan cenderung untuk berhubungan lebih aktif dengan obyek atau aktivitas tersebut. 
Minat dapat dibentuk melalui pengalaman langsung atau pengalaman yang mengesankan yang menyediakan kesempatan bagi individu untuk mempraktekkan, memperoleh umpan balik dan mengembangkan keterampilan yang mengarah pada effikasi personal dan pengharapan atas hasil yang memuaskan (Lent, Brown \& Hacket, dalam Sondari, 2009). Pengaruh keluarga, pendidikan dan pengalaman kerja pertama adalah faktor penting dalam pengembangan minat berwirausaha (Krueger \& Brazeal, 1994; Segal, Borgia, \& Schoenfeld, 2002 dalam Farzier \& Niehm, 2008). Orang tua memberikan dampak kuat pada pemilihan minat berwirausaha, penelitian menunjukkan para wirausaha biasanya memiliki orang tua yang juga seorang wirausaha (Peterman \& Kennedy, 2003 dalam Farzier \& Niehm, 2008). Pendidikan dan pengalaman kerja dapat mempengaruhi pilihan karir dengan mengenalkan ide-ide baru, membangun keterampilan yang diperlukan dan menyediakan akses pada role model (Nabi, Holden \& Walmsley, 2006; Van Auken, Fry, \& Stephens, 2006 dalam Sondari, 2009).

Mereka yang memilih wirausaha sebagai pilihan mereka, memiliki persepsi tertentu mengenai tingkat kemenarikan karir berwirausaha (career attractiveness), tingkat kelayakan berwirausaha (feasibility) dan keyakinan atas efikasi diri (self-efficay beliefs) untuk memulai usaha (Farzier and Niehm, 2008 dalam Sondari, 2009).

Kram (1983) and Shapero dan Sokol (1982) sebagaimana dikutip dalam Sondari (2009) menemukan bahwa pendidikan dan pelatihan mempengaruhi persepsi orang terhadap minat kewirausahaan, dengan menyediakan kesempatan untuk mensimulasikan memulai usaha dan dengan mengamati seorang role model. Sagie and Elizur (1999) mengutip Hisrich yang menyatakan: "entrepreneurship courses taken, increases the interest in starting a new venture ... A strong education base is almost a prerequisite for entrepreneurial activity and company formation in an area". Maka dari itu, pendidikan kewirausahaan harus dirancang sedemikian rupa agar dapat memberikan dampak dalam mendorong minat mahasiswa untuk berwirausaha. Pola pembelajaran kewirausahaan minimal mengandung empat unsur (Suherman, 2008) ditambah satu unsur (Farzier and Niehm, 2008), sebagai berikut: 
1. Pemikiran yang diisi oleh pengetahuan tentang nilai-nilai, semangat, jiwa, sikap dan perilaku, agar peserta didik memiliki pemikiran kewirausahaan.

2. Perasaan, yang diisi oleh penanaman empatisme social-ekonomi, agar peserta didik dapat merasakan suka-duka berwirausaha dan memperoleh pengalaman empiris dari para wirausaha terdahulu.

3. Keterampilan yang harus dimiliki oleh peserta didik untuk berwirausaha. Oleh karena itu dalam konteks ini pembelajaran kewirausahaan membekali peserta didik dengan teknik produksi dan manajemen.

4. Kesehatan fisik, mental dan sosial. Sehubungan dengan hal ini, peserta didik hendaknya dibekali oleh teknik-teknik antisipasi terhadap berbagai hal yang mungkin timbul dalam berwirausaha baik berupa persoalan, masalah maupun risiko lainnya sebagi wirausaha.

5. Pengalaman langsung berupa pemagangan atau melakukan aktivitas didampingi mentor yang kemudian akan dijadikan role model bagi peserta didik.

Minat berwirausaha dapat diukur dengan: (Bhandari, 2007)

1. Prestis sosial, merupakan suatu rasa penghargaan tersendiri yang dirasakan seseorang bila melakukan salah satunya dengan berwirausaha untuk dilihat di masyarakat ataupun diakui oleh lingkungan sehingga menaikkan derajatnya.

2. Tantangan pribadi, merupakan suatu tantangan untuk diri sendiri yang membuat seseorang ingin membuktikan apakah dia mampu atau tidak melakukan suatu hal yang mungkin belum pernah dilakukan sehingga memicu dirinya untuk belajar dan mencoba.

3. Menjadi bos, adalah keinginan untuk menjadi bos suatu saat nanti atau mendirikan usaha sendiri. 
4. Inovasi, merupakan menciptakan sesuatu yang baru ataupun mengembangkan sesuatu yang sudah ada menjadi berbeda dari yang lainnya.

5. Kepemimpinan, merupakan proses mempengaruhi orang lain untuk mencapai tujuan organisasi.

6. Fleksibilitas, merupakan kelonggaran saat memiliki suatu usaha sendiri seperti dari jam kerja yang bisa diatur sendiri.

7. Keuntungan, merupakan laba yang diperoleh dari usaha yang dibukanya sendiri.

Perilaku kewirausahaan dipengaruh oleh faktor internal dan eksternal. Faktor tersebut adalah hak kepemilikan (property right), kemampuan / kompetensi (competency/ability), dan insentif (incentive). Sedangkan faktor eksternalnya adalah lingkungan (environment) (Suryana, 2003). Kerangka penelitian dari penelitian ini adalah sebagai berikut:

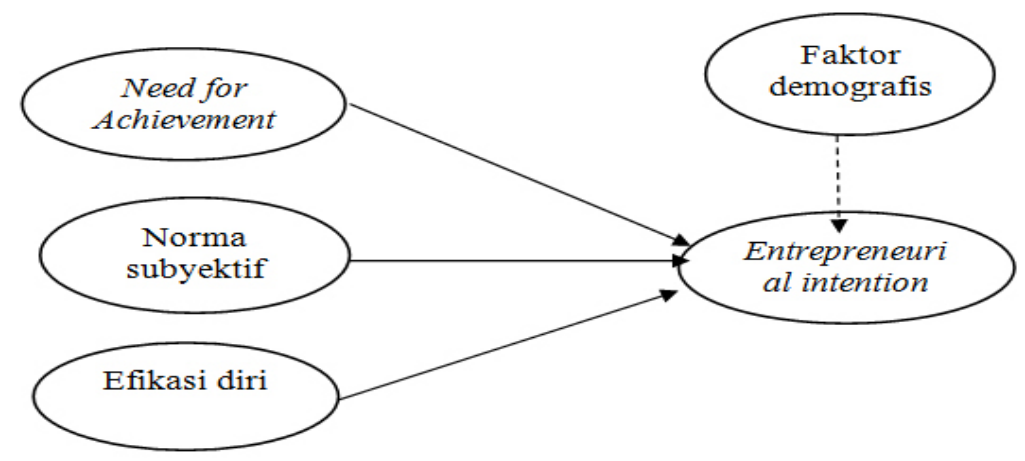

Gambar 1

Kerangka Penelitian

\section{HIPOTESIS}

Hipotesis adalah dugaan sementara akan hasil penelitian, pada penelitian ini hipotesisnya adalah:

H1: Terdapat pengaruh need for achievement terhadap minat berwirausaha dengan faktor demografis sebagai variabel moderating 
$\mathrm{H} 2$ : Terdapat pengaruh norma subyektif terhadap minat berwirausaha dengan faktor demografis sebagai variabel moderating

H3: Terdapat pengaruh efikasi diri kewirausahaan terhadap minat berwirausaha dengan faktor demografis sebagai variabel moderating

\section{METODE PENELITIAN}

\section{Populasi dan Sampel}

Populasi pada penelitian ini adalah mahasiswa STIE AMA Salatiga yang berjumlah 921 orang. Teknik sampling yang digunakan adalah teknik purposive sampling, yaitu pengambilan sampel dengan kriteria atau syarat tertentu (Sugiyono, 2008). Adapun kriterianya adalah: Mahasiswa STIE AMA Salatiga yang sudah mengambil mata kuliah Kewirausahaan. Penentuan jumlah responden yang akan dibagikan adalah 30 orang yang merupakan batas minimal sampel kecil penelitian dan didasarkan pada mahasiswa yang pada semester gasal 2016/2017 sudah atau sedang mengambil mata kuliah kewirausahaan untuk program studi manajemen maupun akuntansi di kelas regular pagi.

\section{Analisis Regresi Uji Nilai Selisih Mutlak}

Penelitian ini menggunakan teknik analisis data yaitu regresi berganda untuk mengetahui pengaruh variabel independen (X) terhadap variabel dependen (Y). Untuk itu diformulasikan model regresi berganda sebagai berikut :

$$
\begin{aligned}
& \mathrm{Y}=\mathrm{a}+\mathrm{b} 1 \mathrm{X} 1+\mathrm{b} 2 \mathrm{X} 2+\mathrm{b} 3[\mathrm{X} 1-\mathrm{X} 2]+\mathrm{e} \\
& \text { Dimana }: \\
& \mathrm{Y}=\text { Minat berwirausaha } \\
& \mathrm{a}=\text { Konstanta } \\
& \mathrm{b} 1 \text { - b3 = koefisien regresi berganda } \\
& \mathrm{X} 1=\text { variabel independen } \\
& \mathrm{X} 2=\text { variabel moderasi } \\
& \mathrm{X} 3=\text { nilai absolut variabel independen }- \text { variabel moderasi } \\
& \mathrm{e}=\text { error / faktor kesalahan }
\end{aligned}
$$




\section{Uji t}

Uji t digunakan untuk menunjukkan seberapa jauh pengaruh satu variabel penjelas/independen secara individual dalam menerangkan variasi variabel dependen , dimana $\alpha=0,05$ (Ghozali, 2006)

\section{Koefisien Determinasi}

Koefisien determinasi digunakan untuk mengetahui seberapa besar variasi dari variabel independen dapat memberikan kontribusi terhadap variabel dependen.

\section{ANALISIS DATA DAN PEMBAHASAN}

Hasil dari uji ini digunakan untuk dapat mengetahui apakah faktor demografi adalah variabel yang dapat memperkuat atau memperlemah pengaruh ketiga variabel independen (need of achievement, subjective norms, self efficacy) terhadap entrepreneurial intention. Dalam uji ini dilakukan tiga kali pengujian sesuai dengan jumlah variabel independen.

Tabel 1

Uji Selisih Nilai Mutlak Variabel Need of Achievement

Coefficients $^{a}$

\begin{tabular}{|c|c|c|c|c|c|c|c|}
\hline \multirow[b]{2}{*}{ Model } & \multicolumn{2}{|c|}{$\begin{array}{c}\text { Unstandardized } \\
\text { Coefficients }\end{array}$} & \multirow{2}{*}{$\begin{array}{c}\text { Standardized } \\
\text { Coefficients } \\
\text { Beta } \\
\end{array}$} & \multirow[b]{2}{*}{$t$} & \multirow[b]{2}{*}{ Sig. } & \multicolumn{2}{|c|}{$\begin{array}{c}\text { Collinearity } \\
\text { Statistics }\end{array}$} \\
\hline & $\mathrm{B}$ & $\begin{array}{l}\text { Std. } \\
\text { Error }\end{array}$ & & & & Tolerance & VIF \\
\hline 1 (Constant) & 8.935 & .321 & & 27.846 & .000 & & \\
\hline Zscore(total_noa) & -.189 & .204 & -.144 & -.926 & .363 & .753 & 1.328 \\
\hline Zscore(total_demografi) & 1.261 & .247 & .961 & 5.111 & .000 & .514 & 1.944 \\
\hline absolut_noa & -.872 & .352 & -.421 & -2.479 & .020 & .631 & 1.585 \\
\hline
\end{tabular}

a. Dependent Variable: total_intention

Dari tabel diatas dapat dirumuskan persamaan regresi $\mathrm{Y}=8,935-0,189 \mathrm{X} 1+1,261 \mathrm{X} 2-$ 0,872Z. Intepretasi dari persamaan tersebut dilihat dari nilai absolut_noa sebagai nilai moderasi, jika dilihat dari nilai signifikansinya sebesar 0,020 lebih kecil dari 0,05 sehingga dapat disimpulkan bahwa faktor demografi merupakan variabel moderasi bagi pengaruh variabel need of achievement terhadap entrepreneurial intention, artinya minat berwirausaha mahasiswa STIE AMA Salatiga dipengaruhi oleh keinginan untuk 
berprestasi dan akan diperkuat oleh faktor demografi yang mendukung yaitu gender dan latar belakang keluarga.

Tabel 2

\section{Uji Selisih Nilai Mutlak Variabel Subjective Norms}

\section{Coefficients $^{a}$}

\begin{tabular}{|l|r|r|r|r|r|}
\hline \multirow{2}{*}{ Model } & \multicolumn{2}{|c|}{} & \multicolumn{2}{c|}{$\begin{array}{c}\text { Standardized } \\
\text { Coefficients }\end{array}$} & \\
\cline { 2 - 4 } & \multicolumn{2}{|c|}{ Unstandardized Coefficients } & \multicolumn{1}{c|}{ Std. Error } & \multicolumn{1}{c|}{ Beta } & \multicolumn{1}{c|}{ Sig. } \\
\hline (Constant) & 7.933 & .314 & & 25.226 & .000 \\
Zscore(total_subnorm) & -.925 & .278 & -.705 & -3.322 & .003 \\
Zscore(total_demografi) & .184 & .286 & .141 & .645 & .525 \\
absolut_subnorm & .215 & .173 & .172 & 1.237 & .227 \\
\hline
\end{tabular}

a. Dependent Variable: total_intention

Dari tabel diatas dapat dirumuskan persamaan regresi $Y=7,933$ $0,925 \mathrm{X} 1+0,184 \mathrm{X} 2+0,215 \mathrm{Z}$. Intepretasi dari persamaan tersebut dilihat dari nilai absolut_subnorm sebagai nilai moderasi, jika dilihat dari nilai signifikansinya sebesar 0,227 lebih besar dari 0,05 sehingga dapat disimpulkan bahwa faktor demografi bukan merupakan variabel moderasi bagi pengaruh variabel subjective norms terhadap entrepreneurial intention, artinya minat berwirausaha mahasiswa STIE AMA Salatiga dipengaruhi oleh norma subyektif tetapi tidak diperkuat atau diperlemah oleh faktor demografi.

Tabel 3

Uji Selisih Nilai Mutlak Variabel Self Eficacy

Coefficients $^{\mathrm{a}}$

\begin{tabular}{|c|c|c|c|c|c|}
\hline \multirow[b]{2}{*}{ Model } & \multicolumn{2}{|c|}{ Unstandardized Coefficients } & \multirow{2}{*}{$\begin{array}{c}\text { Standardized } \\
\text { Coefficients } \\
\text { Beta }\end{array}$} & \multirow[b]{2}{*}{$\mathrm{t}$} & \multirow[b]{2}{*}{ Sig. } \\
\hline & $\mathrm{B}$ & Std. Error & & & \\
\hline (Constant) & 7.864 & .483 & & 16.280 & .000 \\
\hline Zscore(total_self) & -.632 & .222 & -.482 & -2.843 & .009 \\
\hline Zscore(total_demografi) & .979 & .190 & .746 & 5.148 & .000 \\
\hline absolut selfef & .350 & .394 & .154 & .889 & .382 \\
\hline
\end{tabular}

a. Dependent Variable: total_intention 
Dari tabel diatas dapat dirumuskan persamaan regresi $\mathrm{Y}=7,864$ $0,632 \mathrm{X} 1+0,979 \mathrm{X} 2+0,350 \mathrm{Z}$. Intepretasi dari persamaan tersebut dilihat dari nilai absolut_selfef sebagai nilai moderasi, jika dilihat dari nilai signifikansinya sebesar 0,382 lebih besar dari 0,05 sehingga dapat disimpulkan bahwa faktor demografi bukan merupakan variabel moderasi bagi pengaruh variabel self efficacy terhadap entrepreneurial intention, artinya minat berwirausaha mahasiswa STIE AMA Salatiga dipengaruhi oleh efikasi diri tetapi tidak diperkuat atau diperlemah oleh faktor demografi.

\section{Uji Hipotesis}

Hipotesis adalah dugaan sementara akan hasil penelitian, pada penelitian ini hipotesisnya adalah:

a. Jika dilihat dari nilai signifikansinya sebesar 0,020 lebih kecil dari 0,05 sehingga dapat disimpulkan bahwa faktor demografi merupakan variabel moderasi bagi pengaruh variabel need of achievement terhadap entrepreneurial intention, artinya minat berwirausaha mahasiswa STIE AMA Salatiga dipengaruhi oleh keinginan untuk berprestasi dan akan diperkuat oleh faktor demografi yang mendukung yaitu gender dan latar belakang keluarga, atau dengan kata lain $\mathrm{H} 1$ yang menyatakan : Terdapat pengaruh need for achievement terhadap minat berwirausaha dengan faktor demografis sebagai variabel moderating dapat diterima.

b. Jika dilihat dari nilai signifikansinya sebesar 0,227 lebih besar dari 0,05 sehingga dapat disimpulkan bahwa faktor demografi bukan merupakan variabel moderasi bagi pengaruh variabel subjective norms terhadap entrepreneurial intention, walaupun secara parsial norma subyektif memililiki pengaruh yang signifikan terhadap keinginan berwirausaha namun pengaruh tersebut tidak dimoderasi oleh faktor demografi atau dengan kata lain $\mathrm{H} 2$ yang menyatakan terdapat pengaruh norma subyektif terhadap minat berwirausaha dengan faktor demografis sebagai variabel moderating ditolak.

c. Jika dilihat dari nilai signifikansinya sebesar 0,382 lebih besar dari 0,05 sehingga dapat disimpulkan bahwa faktor demografi bukan merupakan 
variabel moderasi bagi pengaruh variabel self efficacy terhadap entrepreneurial intention, walaupun secara parsial efikasi diri memililiki pengaruh yang signifikan terhadap keinginan berwirausaha namun pengaruh tersebut tidak dimoderasi oleh faktor demografi atau dengan kata lain $\mathrm{H} 3$ yang menyatakan terdapat pengaruh efikasi diri kewirausahaan terhadap minat berwirausaha dengan faktor demografis sebagai variabel moderating ditolak.

\section{Pembahasan}

Dari hasil uji selisih nilai mutlak dapat disimpulkan bahwa variabel demografi hanya menjadi moderator bagi variabel need of achievement saja, sedangkan bagi variabel subjective norms dan self efficacy faktor demografi bukan sebagai variabel moderasi. Kesimpulan akhir penelitian ini dapat dikatakan bahwa faktor demografi adalah variabel quasi moderator bukan variabel moderator murni karena faktor demografi hanya berhubungan dengan satu predictor saja yaitu need of achievement. Minat berwirausaha dari mahasiswa STIE AMA Salatiga dipengaruhi oleh tiga variabel yaitu need of achievement, subjective norms dan self efficacy, sedangkan faktor demografi bukan sebagai variabel moderasi yang memperkuat atau memperlemah minat berwirausaha.

\section{SIMPULAN DAN SARAN}

\section{Saran}

Faktor demografi merupakan variabel moderasi bagi pengaruh variabel need of achievement terhadap entrepreneurial intention, artinya minat berwirausaha mahasiswa STIE AMA Salatiga dipengaruhi oleh keinginan untuk berprestasi dan akan diperkuat oleh faktor demografi yang mendukung yaitu gender dan latar belakang keluarga. Secara parsial norma subyektif memililiki pengaruh yang signifikan terhadap keinginan berwirausaha namun pengaruh tersebut tidak dimoderasi oleh faktor demografi. Secara parsial efikasi diri memililiki pengaruh yang signifikan terhadap keinginan berwirausaha namun pengaruh tersebut tidak dimoderasi oleh faktor demografi.

Kesimpulan akhir penelitian ini dapat dikatakan bahwa faktor demografi adalah variabel quasi moderator bukan variabel moderator murni karena faktor demografi hanya berhubungan dengan satu predictor saja yaitu need of achievement. Minat berwirausaha dari mahasiswa STIE AMA Salatiga dipengaruhi oleh tiga variabel yaitu need of 
achievement, subjective norms dan self efficacy, sedangkan faktor demografi bukan sebagai variabel moderasi yang memperkuat atau memperlemah minat berwirausaha.

\section{Saran}

Keterbatasan penelitian ini adalah jumlah sampel yang terbatas, sehingga untuk penelitian yang sejenis dimasa yang akan dating dapat menambah jumlah sampel dan menambah variabel independen atau memasukkan variabel moderator lain yang terkait dengan minat kewirausahaan mahasiswa.

\section{DAFTAR PUSTAKA}

Ajzen, I.1985, "From intentions to actions: a Theory of Planned Behavior", in Kuhl, J. and Beckmann, J. (Eds), Action Control: From Cognition to Behavior, Springer-Verlag, New York, NY, pp. 11-39.

Ajzen, I. 1991. The Theory of Planned Behavior. Organizational Behavior and Human Decision Process, 50, 179-211

Badan Pusat Statistik, www.bps.go.id diakses 5 Juli 2010

Baumol, W. J., Litan, R. E., \& Schramm, C. J. (2007). Sustaining entrepreneurial capitalism. Capitalism and Society, 2(2) Article 1. Available at: http://www.bepress.com/cas/vol2/iss2/art1

Indiarti, N. dan Rokhima R. 2008, Intensi Kewirausahaan Mahasiswa: Studi Perbandingan Antara Indonesia, Jepang dan Norwegia, Jurnal Ekonomika dan Bisnis Indonesia, Vol. 23, No. 4.

Ismail, M., Shaiful Annuar Khalid, Mahmod Othman, Norshimah Abdul Rahman, Kamsol Mohamed Kassim, Rozihana Shekh Zain, Entrepreneurial intention among Malaysian Undergraduates, International Journal of Business and Management, Vol 4, No. 10, Oktober 2009

Licht, A. N. Entrepreneurial spirit and what the law can do about it. Comparative Labor Law \& Policy Journal, Vol. 28 No. 4, 2007.

Mazzarol, T., T. Volery, N. Doss, dan V. Thein, 1999. "Factors influencing small business startups". International Journal of Entrepreneurial Behaviour and Research 5 (2): 48-63.

Scapinello, K. F., 1989. "Enhancing differences in the achievement attributions of high and low motivation groups". Journal of Social Psychology 129 (3): 357-363. 
Segal, G., \& Borgia, D., Schoenfeld, J., 2005. The Motivation to Become an Entreprenur. International Journal of Entrepreneurial Behavior \& Research, 11, 42-57

Seagal, G; Borgia and Jerry Schoenfeld, 2005, The Motivation To Become An Entrepreneur International Journal of Entrepreneurial Behaviour \& Research Vol. 11 No. 1

Shane, S., Edwin A. Locke, Christoper J. Collins, 2003, Entrepreneurial Motivation, Human Resource Management Review 13, 257-279.

Tkachev, A., dan L. Kolvereid, 1999. "Self-employment intentions among Russian students". Entrepreneurship \& Regional Development 11: 269-280.

Wijaya, T., 2007. Hubungan Adversity Intelligence dengan Intensi Berwirausaha (Sudi Empiris pada Siswa SMKN 7 Yogyakarta). Jurnal Manajemen dan Kewirausahaan, 9, 117-127

Wijaya, T., 2008, Kajian Model Empiris Perilaku Berwirausaha UKM DIY dan Jawa Tengah Jurnal Manajemen dan Kewirausahaan, Vol.10, No. 2.

Wijaya, T.,, 2008. Studi Meta-Analisis Hubungan Efikasi Diri dan Sikap Toleransi Risiko Dengan Intensi Berwirausaha. Program Doktor Psikologi UGM.

Zain, Z. M. Amalina Mohd Akram, Erlane K Ghani, 2010, Entreprenurial Intention Among Malaysian Business Students, Canadian Social Science, Vol. 6, No. 3, pp. 34-44.

Zhao, H., Seibert, S.E., \& Hills, G.E., 2005. The Mediating Role of Self Efficacy in the Development of Entrepreneurial intention. Journal of Applied Psychology, 90, $1265-1271$ 